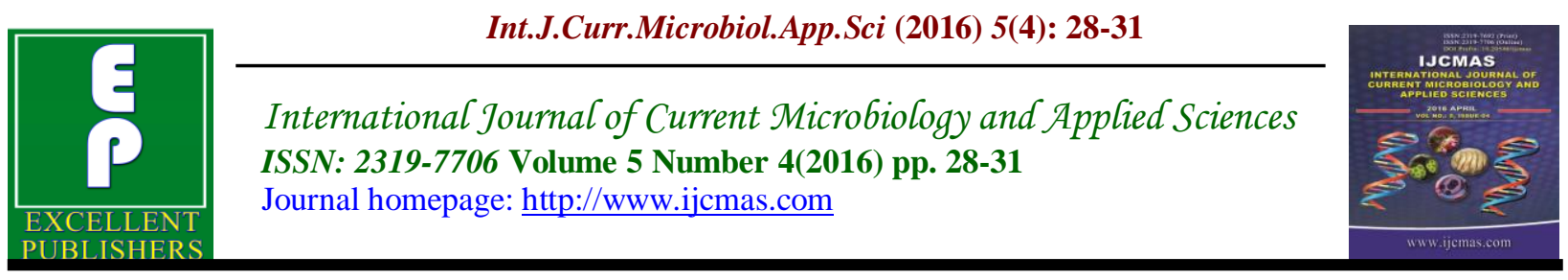

Original Research Article

http://dx.doi.org/10.20546/ijcmas.2016.504.005

\title{
Gynecological Morbidity among the Rural women of Andaman Islands-Community Based Study
}

\author{
Rehnuma Parvez ${ }^{*}$, A. P. Sugunan ${ }^{1}$, M. K. Saha ${ }^{2}$, N. Muruganandam ${ }^{1}$ \\ and R.Thamizhmani ${ }^{1}$ \\ ${ }^{1}$ Regional Medical Research Centre (ICMR), Post Bag No.13, Dollygunj, \\ Port Blair, Andaman and Nicobar Islands-744101, India \\ ${ }^{2}$ G.B. Pant Hospital, Port Blair, Andaman \& Nicobar Islands - 744101, India \\ *Corresponding author
}

\begin{abstract}
A B S T R A C T
Keywords

Gynecological,

Women,

Health,

Prevalence.

\section{Article Info}

Accepted:

08 March 2016

Available Online:

10 April 2016

This study aim to gynaecological morbidity refers to the conditions of reproductive ill-health which is not related to pregnancy and its related complications. The present study was conducted in Andaman district so as to measure the prevalence of gynaecological morbidity among the rural women of this island. Women in the age group 20-59 years were included in the study. Morbidity for gynaecological problem was found to be $13 \%$ among women in these islands. The most common gynecological problem reported was menstrual problems present among $75 \%$ of women followed by low backache present in $42 \%$ of women and chronic vaginal discharge in $24 \%$. Dysmennorhoea was the most common menstrual problem complaint present in 34\%. Among 241 pap smears screened, majority 58\% were inflammatory pap. The present study reports for the first time the prevalence of gynaecological morbidity among the rural women in these islands. This study the overall prevalence of gynaecological morbidity is only $13 \%$ which is lower than that reported from similar studies. This low prevalence can be attributed to the better education and a good socioeconomic status and easy accessibility to health care services in this island.
\end{abstract}

\section{Introduction}

Gynecological health is an important component of woman's health status as it has a remarkable impact on the quality of life. It affects not only the reproductive health but also her over all physical health status and ability to perform her daily routine activities. Health problems related to female reproductive tract constitute the leading cause of ill-health in women of reproductive age group worldwide especially to those in developing countries (UNPFA, 2014). In the recent years, the gynaecological morbidities of rural women especially in the developing countries have received increased attention.Gynecological morbidity refers to the conditions of reproductive ill-health which is not related to pregnancy and its 
related complications (Younis et al., 1993). The Andaman and Nicobar Island is situated in Bay of Bengal, forming an arched string of about 572 big and small Islands between $6^{\circ}$ and $14^{\circ} \mathrm{N}$ latitudes and between $92^{\circ}$ and $94^{\circ} \mathrm{E}$ longitudes. The total area of this island is 8249 sq. $\mathrm{km}$, where Andaman district is 6408 sq. $\mathrm{km}$. The present study was conducted in the Andaman district so as to measure the prevalence of gynecological morbidity among the rural women of this island. The study was carried out in the villages of rural areas Andaman Islands of South Andaman and North \& Middle Andaman. Villages were the sampling unit. The entire household in the selected village were surveyed by conducting house to house visit. All the women in the age group 20-59 years were included in the study. Ethical clearance was obtained from the Institutional Ethics Committee for Human Research, Regional Medical Research Centre, Port Blair. An informed consent was obtained from all the study subjects after explaining the purpose of the study to them. A pretested structured questionnaire was administered to the subjects seeking information regarding demographic profile i.e., age, religion, occupation, monthly income, menstrual history, marital history and gynecological and medical history by trained staff. Detailed information on menstrual and obstetrichistories, as well as presence of any gynaecological complaints was recorded. The menstrual problems, abnormal vaginal discharge, chronic pelvic pain, low backache, something coming out from vagina (as sign of genital prolapse), pain or burning sensation while passing urine (as sign of dysuria) were the gynaecological complaints which were recorded.A total 9961 women were surveyed in our study, among them 4156 (41\%) were in the age group 26-35 years, 2319(23\%) were between the age group of 20-25 years. The mean age of the women were
33.6( $\mathrm{SD} \pm 9.85)$. The mean age at menarche was $12(\mathrm{SD} \pm 0.9)$. The mean age at marriage was 19 years. Majority of the women were Hindus (70\%), followed by Muslims (15\%). Only $9 \%$ women were illiterate, $35 \%$ were educated till middle school level and $32 \%$ studied upto senior secondary level. $90 \%$ of the women were married and only $2 \%$ were widow and $8 \%$ were unmarried.

Mean number of live children per woman was 2 children, $12 \%$ of ever married women gave a history abortion. About $83 \%$ of the ever married women used family planning methods. The most common family planning method used was permanent method of sterilization by abdominal tubectomy or laparoscopic ligation in $65 \%$ followed by use of condoms in 17\%.Among the 9961 women surveyed, 1272(13\%) had gynecological problems. Among the symptomatic women the mean age at marriage was 19.6 years $\left(\mathrm{SD}_{ \pm}\right.$3.6) mean age at menarche was $12.49(\mathrm{SD} \pm$ 0.9). The mean number of live children was 1.7(SD +1.2 ).

The most common gynecological problem reported was menstrual problems present among 950 (75\%) of women followed by low backache present in 536(42\%) of women. Chronic vaginal discharge was also prevalent in 308(24\%) and dysuria in $204(21 \%)$ as shown in Figure No.1.Among the menstrual problem dysmennorhoea was present in 323(34\%) followed by metorrhagia in 206(22\%), oligomennorhoea in $150(16 \%)$, polymennorhoea 122 (13\%), $85(9 \%)$ menorrhagia and amenorrhea in $64(7 \%)$. Some pregnancy related morbidities were also present in the study subjects as $56 \%$ of the women screened gave history of antenatal medical illness, the most common being gestational hypertension present in $54 \%$,followed by gestational diabetes mellitus in $22 \%$ and anemia during pregnancyin $25 \%$. 
Table.1 Distribution of Cervical Cytological Findings in the Subjects

\begin{tabular}{|l|c|c|}
\hline Pap smear finding & No. of subjects $(\mathbf{n = 2 4 1})$ & Percentage $(\%)$ \\
\hline Normal & 92 & 38 \\
\hline Inflammatory & 139 & 58 \\
\hline ASCUS & 4 & 1.6 \\
\hline LSIL & 3 & 1.2 \\
\hline AGUS & 1 & 0.4 \\
\hline NRS & 1 & 0.4 \\
Scant cellularity & 1 & 0.4 \\
Obscured by blood & & - \\
\hline
\end{tabular}

ASCUS - Atypical squamous cells of undetermimed significance, LSIL - Low grade squamous intraepithelial lesion, AGUS - Atypical glandular cells of undetermined significance,NRS

Figure.1 Prevalence of the Gynaecological symptoms among subjects

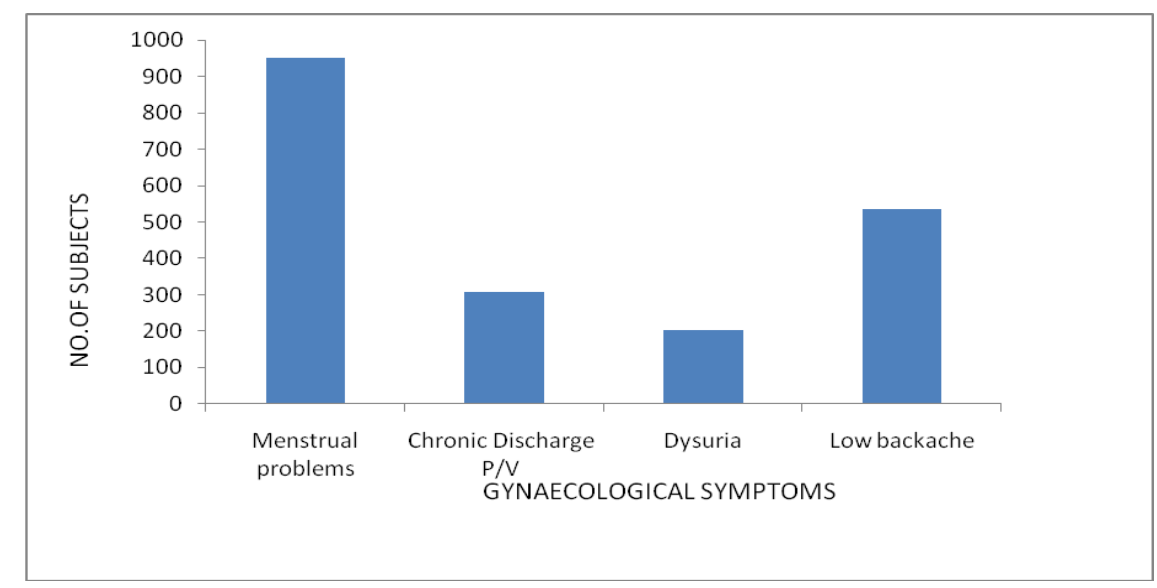

Pap smear was collected from 241 among the 308 women who complained of chronic vaginal discharge. The cytological findings are shown in Table 1.Majority of the subjects had an inflammatory pap (58\%).

In the present study the overall prevalence of gynaecological morbidity is only $13 \%$ which is lower than that reported from similar studies (Sridhar et al., 1991; Judith et al., 1989; Bang et al., 1989; Bhatia et al., 1995; Sandhya 1997; Indra et al., 2003). In a baseline survey conducted by Center for Operations Research and Training in the state of Uttar Pradesh and Rajasthan the prevalence gynaecological morbidity varied from 28 to $37 \%$ (Nandan et al., 2002; Rathore et al., 2003). On the other hand in the studies conducted in the urban slums of Mumbai and west Bengal a much higher prevalence of gynaecological problems of $75 \%$ and $65.84 \%$ were reported respectively (Brabin et al., 1998; Suneela, et al., 2001). In the present study menstrual problems are the most common gynaecological morbidity among study subjects similarly in a study done by (Zafer et al., 2004) also menstrual problems were the most common gynaecological morbidity present. The next common gynecological problem was low back ache. In a study done by (Poornima et al., 2013) in Karnataka also the most common gynaecological problems was menstrual problem followed by low backache. This is the first community based cross-sectional study reporting the 
prevalence of gynaecological morbidity among the rural women of these remote Islands. The low prevalence of gynaecological morbidities here can be attributed to the better education and a good socioeconomic status and easy accessibility to health care services in these islands.

\section{References}

Bang, R.A., Bang, A.T., Batule, M., Choudhary, Y., Sarmukaddam, S., Tale, O. 1989. High prevalence of gynaecological diseases in rural Indian women. Lancet, 1: 85-88.

Bhatia, J.C., Cleland, J. 1995. Self-reported symptoms of gynaecological morbidity and their treatment in south India. Stud. Fam Plann., 26(4): 203-16.

Brabin, L., Gogate, A., Karande, A., Khanna, R., Dolimore, N. 1998. Reproductive tract infections, gynecological morbidity and HIV sero prevalence among women in Mumbai, India. WHO Bull., 76: 227-235.

Improving reproductive health. Population issues. UNPFA. 2014. Available at: http://www.unfpa.org/rh/index.htm. [Last accessed on 26/08/2014].

Indra, P., Kambo, B., Dhillon, S., Singh, P., Saxena, B.N., Saxena, N.C. 2003. Self Reported gynaecological problems from twenty three districts of India (AN ICMR Task Force Study) Indian J. Comm. Med., 28(2): 67-73

Nandan, D., Misra, S.K., Sharma, A., Jain, M. 2002. Estimation of Prevalence of RTIs /STDs Among Women of Reproductive Age Group in District Agra. Indian J. Comm. Med., 27(3): 45-49.

Poornima, S., Katti, S.M., Mallapur, M.D., Vinay, M. 2013. Gynecological problems of married women in the reproductive age group of urban Belgaum, Karnataka Al
Ameen J. Med. Sci., 6(3): 226-230.

Rathore, M., Swami, S.S., Gupta, B.L., Sen, V., Vyas, B.L., Bhargav, A., Vyas, R. 2003. Community based study of self reported morbidity of reproductive tract among women of reproductive age in rural area of Rajasthan. Indian J. Comm. Med., 28(3): 24-28.

Sandhya, B. 1997. Gynaecological morbidityThe ignored tragedy. J. Fam. Wel., 43(2): 58-67.

Sridhar, S., Lata, D., Pankar, S. 1991. Womens' health in rural Gujarat-Sewarurals' experience. Proceedings of the Workshop on improving Young Womens' Health \& Development. Indian Council of Med. Res., 1-9.

Suneela, G., Meenakshi, S., Malti, M. 2001. Perceived Reproductive Morbidity And Health Care Seeking Behaviour Among Women In An Urban Slum. Health and Population - Perspectives and Issues, 24(4): 178-188.

Wasserheit, J.N., Harris, J.R., Chakraborty, J., Kay, B.A., Mason, K.J. 1989. Reproductive Tract Infections in a family planning population in rural Bangladesh. Stud. Fam. Plann., 20(2): 69-80.

Younis, N., Khattab, H., Zurayk, H., ElMouelhy, M., Amin, M.F., Farag, A. 1993. A community study of gynecological and related morbidities in rural Egypt. Stud. Fam. Plann., 24(3): 175-186.

Zafar, S., Mahmood, G. 2004. Burden of Gynaecological Disease in a Tertiary Hospital: two years audit of Outpatient Department at PIMS. J. Pak. Med. Assoc., 54(10): 513-5.

\section{How to cite this article:}

Rehnuma Parvez, A.P.Sugunan, M.K. Saha, N. Muruganandam and R.Thamizhmani. 2016. Gynecological Morbidity among the Rural women of Andaman Islands-Community Based Study. Int.J.Curr.Microbiol.App.Sci. 5(4): 28-31. doi: http://dx.doi.org/10.20546/ijcmas.2016.504.005 